\title{
PENDAMPINGAN JAMA'AH YASINTA DAN PENGAJIAN NURUL HIDAYAH MELALUI MAUIDLOH HASANAH UNTUK MENGUBAH MINDSET KONSERVATIF WARGA DESA JEGULO KECAMATAN SOKO KABUPATEN TUBAN
}

\author{
Rinwanto $^{1}$, Malia Fransisca ${ }^{2}$ \\ ${ }^{1}$ Pendidikan Agama Islam, Tarbiyah, IAINU Tuban \\ ${ }^{2}$ Bahasa dan Sastra Arab, Adab, IAI Sunan Giri Bojonegoro \\ ${ }^{1}$ J1. Manunggal No 10-12, Sukolilo, Kec. Tuban, Kabupaten Tuban \\ ${ }^{2}$ Jl. Ahmad Yani No.10, Jambean, Sukorejo, Kec. Bojonegoro, Kabupaten Bojonegoro \\ $\underline{\text { Rinwanto@stitmatuban.ac.id }}^{1}, \underline{\text { MALIAFRANSISCA2018@ gmail.com }}{ }^{2}$
}

\begin{abstract}
ABSTRAK
YASINTA dan Pengajian Nurul Hidayah merupakan organisasi keagamaan yang rutin dilakukan oleh warga Desa Jegulo Kecamatan Soko Kabupaten Tuban tiap satu minggu sekali. Mayoritas jama'ah YASINTA dan Pengajian Nurul Hidayah adalah warga Desa Jegulo RT. 14 yang sudah berusia di atas 45 tahun. Hal ini berdampak pada pelaksanaan kegiatan rutin tersebut hanya sebatas melanjutkan aktifitas warisan warga terdahulu, tanpa adanya pemikiran-pemikiran untuk mengadakan kegiatan baru yang inovatif dan inspiratif. Oleh karena itu, peneliti menganggap perlu adanya pendampingan supaya kegiatan rutinan tersebut lebih bermakna. Penelitian pengabdian ini menggunakan metode PRA (Participatory Rural Appraisal) dengan pendekatan mauidloh hasanah. Dalam hal ini, peneliti bekerja sama dengan beberapa pengurus YASINTA dan Pengajian Nurul Hidayah untuk mengagendakan kegiatan yang mampu menambah wawasan keagamaan warga Desa Jegulo dengan mengundang orang yang ahli dalam bidangnya yaitu kyai atau ustadh untuk memberikan taushiyah setiap satu minggu sekali. Hasil dari penelitian pengabdian ini adalah setelah adanya stimulus keagamaan melalui mauidloh hasanah, $75 \%$ warga Desa Jegulo mengubah mindsetnya menjadi lebih baik. Warga Desa Jegulo RT. 14 berlomba-lomba dalam kebaikan seperti semangat bergotong royong, bersikap lebih terbuka dan memiliki wawasan yang luas juga modern.
\end{abstract}

Kata Kunci: Organisasi Keagamaan, Mauidloh Hasanah, Pola Pikir

\begin{abstract}
YASINTA and Nurul Hidayah recitation are religious organizations that are routinely carried out by humans of Jegulo Village, Soko District, Tuban Regency, once a week. The majority of the jama'ah YASINTA and Nurul Hidayah recitation are humans of the Jegulo RT Village. 14 who are over 45 years old. This has an impact on the implementation of these routine activities only to continue the activities of the legacy of previous humans, without any ideas for holding new innovative and inspiring activities. Therefore, the researchers considered need for assistance so that routine activities were more meaningful. This community service research uses the PRA (Participatory Rural Appraisal) method with the mauidloh hasanah approach. In this case, the researcher collaborated with YASINTA administrators and Nurul Hidayah recitation to schedule activities that can increase to the religious insight of the humans of Jegulo Village with invited inviting people who are experts in their fields, namely kyai or ustadh to give taushiyah once a week. The result of this dedication research is that after the existence of a religious stimulus through mauidloh hasanah, 75\% of Jegulo Village humans change their mindset for the better. Humans of Jegulo Village, RT. 14 competited in kindness such as the spirit of mutual cooperation, being more open and having broad and modern insights.
\end{abstract}

Keywords: Religious Organization, Mauidloh Hasanah, Mindset 


\section{PENDAHULUAN}

Mindset merupakan kepercayaan-kepercayaan yang mempengaruhi sikap seseorang atau cara berpikir yang menentukan perilaku dan cara pandang seseorang (Yuli Hartanti, 2009).

Dalam pandangan S. Effendy, mindset merupakan pandangan seseorang yang sangat mempengaruhi dirinya dalam menghadapi suatu masalah. Mindset terbentuk dari asumsi yang dimiliki seseorang yang tertanam sangat kuat. Ketika mindset sudah sangat kuat itulah akhirnya mampu menciptakan dorongan yang kuat pula dalam membentuk perilaku. Sehingga perilaku seseorang akan berubah jika mindset itu berubah (S. Effendy, 2017).

Ilham Burhanudin mengatakan bahwa seorang guru harus memiliki mindset yang benar dan mampu memberikan pengaruh positif terhadap peserta didik sehingga mampu mengembangkan wawasan peserta didik (Ilham Burhanudin, 2018). Istilah guru dan murid oleh Ilham Burhanudin jika diintegrasikan dengan penelitian ini adalah para kyai atau ustadh, jama'ah YASINTA dan Pengajian Nurul Hidayah yang akan dijelaskan secara detail pada keterangan berikutnya.

Perubahan mindset ini juga menjadi standar ukuran keberhasilan dalam penelitian Sri Wahyuni. Temuan penelitian yang diperoleh Sri Wahyuni dalam aksi pendampingan anak jalanan adalah keberhasilan mendampingi anak jalanan yang dulunya memiliki kepribadian tidak bagus, minder, tidak mampu, tidak berharga, tidak memiliki cita-cita, diubah mindsetnya menjadi pribadi yang semangat, memiliki cita-cita tinggi sebagaimana anak-anak pada umumnya (Sri Wahyuni, 2009).

Dari uraian di atas dapat disimpulkan bahwa mindset merupakan sikap yang sangat mempengaruhi seseorang dalam bertindak. Sehingga seseorang harus mampu membentuk mindset sebaik mungkin supaya seseorang memiliki perilaku yang baik pula. Karena bentuk riil dari mindset itu adalah tingkah laku kita sehari-hari. Untuk membentuk mindset yang baik sesuai norma susila dan agama, maka kita butuh yang namanya habit (pembiasaan) dan lingkungan yang mendukung.

Sejalan dengan problematika terkait mindset yang telah diuraikan di atas, peneliti juga menemukan problematika yang serupa di Desa Jegulo RT. 14 Kecamatan Soko Kabupaten Tuban. Desa Jegulo merupakan salah satu desa yang ada di Kecamatan Soko Kabupaten Tuban. Secara geografis Desa Jegulo sebelah utara berbatasan dengan Desa Klumpit dan Nguruan, sebelah timur berbatasan dengan Desa Nguruan dan Sumurcinde Sebelah setalatan 
berbatsan dengan Desa Bangunrejo dan sebelah barat berbatasan dengan Desa Klumpit dan Prambon Tergayang.

Mayoritas warga Desa Jegulo berprofesi sebagai petani khususnya warga Rt. 14, sehingga ini mempengaruhi cara berpikir (mindset) sebagian warga Desa Jegulo Rt. 14 yang terkenal masih kolot/terbelakang. Meskipun sudah ada beberapa warga atau pemuda Desa Jegulo yang merantau ke luar kota, apakah untuk bekerja atau menuntut ilmu, namun hal itu belum mampu mengubah mindset mayoritas warga Desa Jegulo. Karena meskipun ada warga yang memiliki ilmu pengetahuan yang baik, belum tentu mampu memberikan pengaruh besar terhadap warga setempat, tetap dalam hal ini sesepuhlah yang dianggap memiliki otoritas lebih.

Warga Desa Jegulo RT. 14 mayoritas penganut organisasi Nahdlatul Ulama (NU). Kegiatan keagamaan yang menjadi identitas warga Nahdliyin adalah yasinan dan tahlilan. Kegiatan tersebut biasanya dilakukan bersama-sama pada hari Kamis malam Jumat dengan mengirim doa yang ditujukan kepada keluarga yang sudah meninggal dunia. Kegiatan itu juga selalu dilakukan warga Desa Jegulo RT. 14 yang mayoritas dihadiri oleh warga yang usianya sudah di atas 45 tahun. Jama'ah yasin dan tahlil warga Desa Jegulo RT. 14 diberi nama "YASINTA" yaitu kepanjangan dari Yasin dan Tahlil. Selain membaca yasin dan tahlil, ada juga kegiatan keagamaan lainnya yang dilakukan warga Desa Jegulo RT. 14 seperti diba'an, pembacaan istighotsah dan manaqiban. Perkumpulan tersebut diberi nama "Pengajian Nurul Hidayah" dengan harapan kegiatan rutin tersebut mampu membawa warga Desa Jegulo RT. 14 mendapatkan ridho Allah SWT dan dibukakan pintu hidayah-Nya.

Seiring berjalannya waktu, sedikit demi sedikit semangat jama'ah YASINTA dan Pengajian Nurul Hidayah dalam mengikuti kegiatan rutin itu semakin kendur. Hal itu disebabkan oleh aktifitas yang dilakukan monoton. Artinya tidak ada kegiatan baru yang mampu menumbuhkan semangat jama'ah. Akhirnya jumlah jama'ah yang aktif mengikuti kegiatan rutin yang biasa dilaksanakan setiap minggu sekali semakin sedikit.

Tidak berhenti di situ, muncul lagi problematika yang berupa terbentuknya sikap jama'ah yang otoriter dan inklusif. Hal itu disebabkan oleh kurangnya jama'ah mengikuti informasi-informasi yang disampaikan pengurus jama'ah YASINTA dan Pengajian Nurul Hidayah setelah kegiatan rutin selesai. Di saat banyak jama'ah yang tidak hadir, maka mereka tidak mengetahui informasi terbaru. Akibatnya, saat panitia YASINTA dan Pengajian Nurul Hidayah membuat kebijakan baru atau hendak mengadakan kegiatan-kegiatan baru, 
banyak jama'ah yang tidak mengetahuinya. Dari situlah mulai adanya miscommunication antara jama'ah dan panitia YASINTA maupun Pengajian Nurul Hidayah.

Dari latar belakang permasalahan yang muncul di atas, maka peneliti ingin melakukan pendampingan dan pengembangan terhadap jama'ah YASINTA dan Pengajian Nurul Hidayah, dengan harapan munculnya kesadaran jama'ah untuk semangat lagi mengikuti kegiatan rutin yasinan dan tahlilan, berperilaku lebih religius, guyup, rukun, gotong royong, dan mengamalkan nilai-nilai agama dalam kehidupan sehari-hari.

\section{METODE}

Pengabdian kepada masyarakat ini menggunakan metode Participatory Rural Appraisal (PRA) adalah suatu metode pendekatan dalam proses pemberdayaan dan peningkatan partisipasi masyarakat, yang menekankan pada keterlibatan masyarakat dalam keseluruhan kegiatan pembangunan (Wiwik D. Pratiwi, 2007).

Istilah participatory dalam PRA menjadikan peneliti berupaya melebur ke dalam situasi dan kondisi masyarakat kelompok sasaran dengan menempatkan diri sebagai insider yaitu pihak yang berada dalam kelompok masyarakat sasaran serta turut aktif di dalam program kegiatan. Dari hal ini diharapkan peneliti mampu menggali lebih dalam permasalahan yang ada di dalam masyarakat serta menyerap aspirasi masyarakat sehingga pemecahan masalah yang ditawarkan mampu mengcover dan mengakomodasi kebutuhan masyarakat (Bambang Hudayana, dkk, 2019).

Dalam pengabdian ini, langkah pertama yang dilakukan peneliti adalah wawancara dengan masyarakat desa, baik perangkat, tokoh masyarakat maupun penggerak kegiatan. Hasil dari wawancara tersebut, ditemukan hambatan maupun kendala yang dapat diklasifikasikan sebagai berikut:

a. Kurangnya perhatian sebagian masyarakat terhadap eksistensi kegiatan,

b. Minimnya anggota yang mahir melakukan keagamaan putra,

c. Turunnya hujan yang terkadang menurunkan semangat untuk berangkat ke acara kegiatan, dan

d. Minimnya remaja yang ikut kegiatan tersebut yang mana kegiatan ini didominasi oleh para orang tua.

(Syakur, Wawancara Tokoh Masyarakat, di Desa Jegulo Kecamatan Soko Kabupaten Tuban pada tanggal 15 Agustus 2020) 
Pasca berbincang-bincang dengan pihak terkait, peneliti dan masyarakat mengetahui permasalahan yang ada di Desa Jegulo RT. 14 ini, sehingga peneliti memberikan saran untuk mengadakan musyawarah guna untuk mencari solusi yang tepat.

\section{HASIL DAN PEMBAHASAN}

Kegiatan pengabdian masyarakat di Desa Jegulo diawali dengan menganalisis problem sosial di RT. 14 mulai dari pendidikan agama dalam pandangan masyarakat, kondisi pemahaman keagamaan masyarakat hingga perkembangan kegiatan keagamaan masyarakat.

Kegiatan keagamaan masyarakat Desa Jegulo RT. 14 itu dimulai sekitar tahun 2013 atas inisiasi Bpk. Syakur (mantan ketua RT), Bpk. Maulan ketua RT. 14 yang menjabat saat itu, Bpk. Juarno (tokoh masyarakat) serta dibantu tokoh masyarakat sekitar untuk kegiatan bapak-bapak. Untuk ibu-ibu dan remaja putri belum ada rutinan keagamaan.

Ditengah-tengah perjalanan, kegiatan keagamaan bapak-bapak (tahilan, yasinan, sholawatan) mengalami kemunduran yang berakibat pada kondisi sosial, budaya dan agama yang berlaku di Desa Jegulo. Kegiatan ini hampir vakum pada tahun 2016. Hal ini disebabkan beberapa faktor di antaranya:

a. Minimnya kader,

b. Kurangnya perhatian dan kesadaran masyarakat tentang pendidikan keagamaan yang bersifat kegiatan rutinan seperti tahlilan khususnya bagi kaum remaja,

c. Terlalu sibuknya masyarakat dengan pekerjaan masing-masing terutama para remaja,

d. Mindset konservatif sebagian warga khususnya kelompok tua, dan

e. Kurangnya syiar terkait nilai-nilai Islam.

(Maulan, Wawancara Tokoh Masyarakat, di Desa Jegulo Kecamatan Soko Kabupaten Tuban pada tanggal 09 Agustus 2020)

Namun berkat kerja keras para tokoh masyarakat, kegiatan keagamaan putra tersebut masih diaktifkan dan berupaya untuk bisa istiqomah meskipun yang aktif hadir hanya beberapa orang. Dengan semangat, mereka tetap melaksanakan rutinan tersebut, meskipun masih terdapat banyak kekurangan maupun suara sumbang dari berbagai penjuru. (Juarno, Wawancara Tokoh Agama, di Desa Jegulo Kecamatan Soko Kabupaten Tuban pada tanggal 12 Agustus 2020).

Selain itu, faktor yang mempengaruhi kurang aktifnya jama'ah menurut Muhammad Lantip saat peneliti mengadakan wawancara yaitu minimnya loyalitas para pemuda atas 
kegiatan-kegiatan yang diadakan oleh desa. Sehingga berdampak pada kurangnya kekompakan pada saat kegiatan berlangsung (Muhammad Lantip, Wawancara Ketua RT. 14, di Desa Jegulo Kecamatan Soko Kabupaten Tuban pada tanggal 16 Agustus 2020)

\section{Analisis Tawaran Solusi}

Setelah melihat dan menimbang berbagai persoalan yang ada, berawal dari hasil wawancara lepas dengan tokoh masyarakat Desa Jegulo, maka peneliti mencoba menawarkan solusi di antaranya:

a. Meminta kesadaran masyarakat, khususnya para remaja dengan cara melibatkan mereka dalam musyawarah supaya ikut serta dalam menyemarakkan kegiatan keagamaan putra,

b. Mengadakan musyawarah bersama dengan tokoh terkait masyarakat;

c. Mengadakan pengkaderan terhadap para remaja maupun anak-anak untuk bisa membawakan kegiatan keagamaan putra sehingga kegiatan tersebut tetap bisa terlaksana dengan baik,

d. Mengagendakan kegiatan dakwah kepada masyarakat melalui mauidloh hasanah yang mampu menambah wawasan keagamaan warga Desa Jegulo RT. 14 dengan mengundang orang yang ahli dalam bidangnya yaitu kyai atau ustadh untuk memberikan taushiyah setiap satu minggu sekali setelah acara tahlilan selesai walaupun durasi waktu hanya 7 menit.

Setelah pendampingan itu dilakukan, peneliti memberikan solusi dan dukungan kepada masyarakat Desa Jegulo untuk selalu semangat dalam rangka merealisasikan programprogram baru yang inovatif dan inspiratif, sehingga kegiatan keagamaan maupun sosial di Desa Jegulo kembali hidup dan mengalami kemajuan.

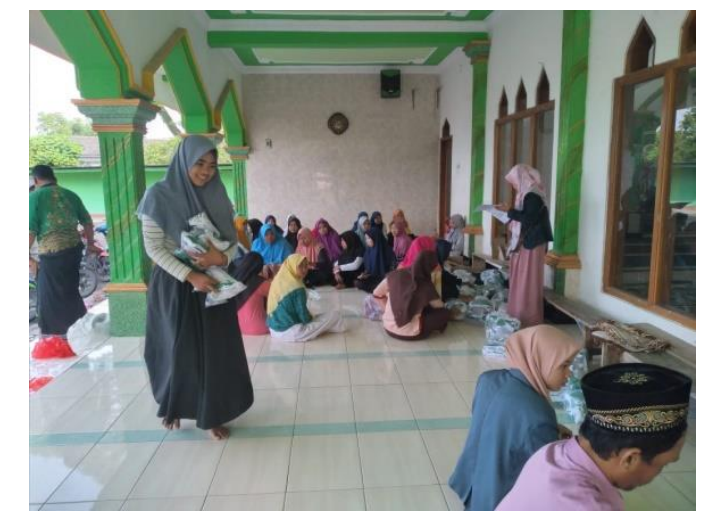

Gambar 1. Pembagian Masker Saat Pandemi oleh Remaja Masjid Darul Mutaqien Desa Jegulo 


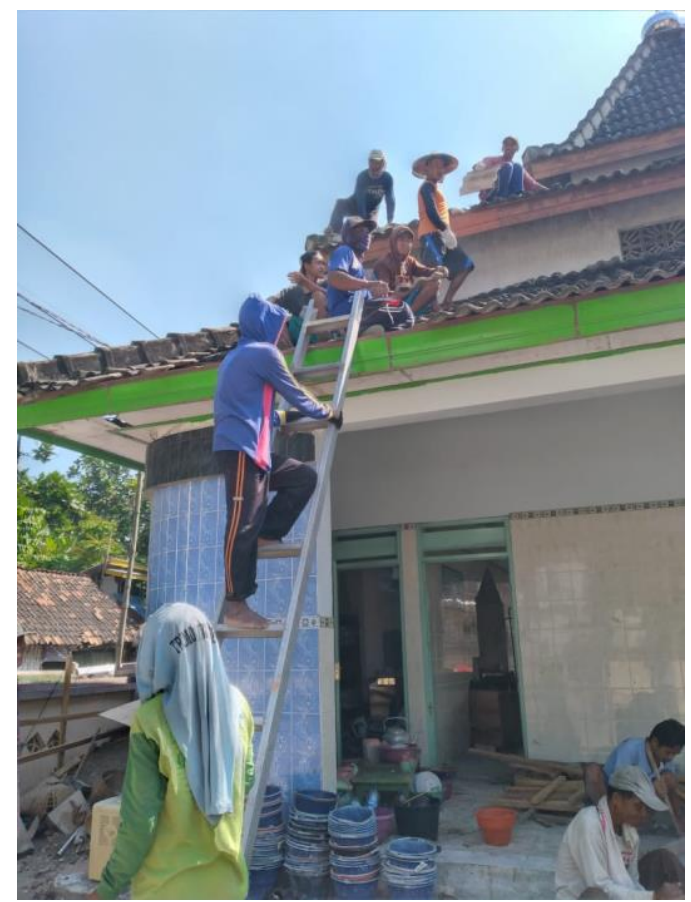

Gambar 2. Renovasi Masjid Al-Ikhlas, bekas bahan bangunan genteng kayu yang masih layak pakai digunakan untuk pembangunan musholla Desa Jegulo RT. 14

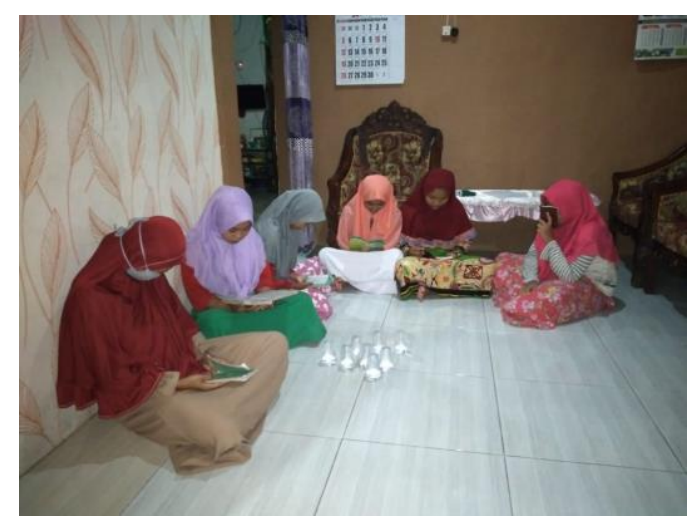

Gambar 3. Kaderisasi Pemuda YASINTA Desa Jegulo RT. 14

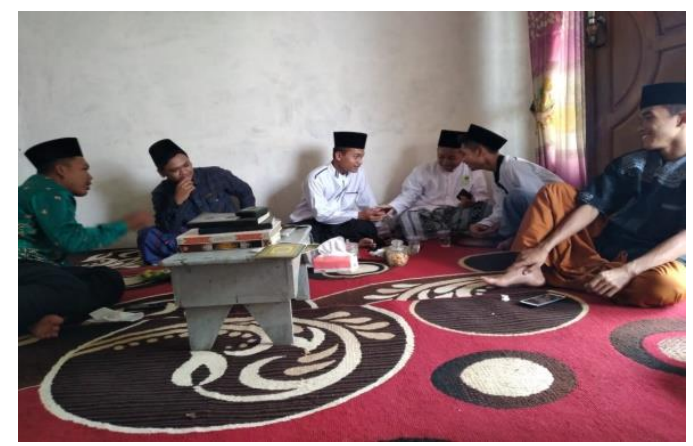

Gambar 4. Khataman Qu'ran Pemuda Desa Jegulo 


\section{SIMPULAN}

Hasil dari penelitian pengabdian ini adalah setelah adanya stimulus keagamaan melalui mauidloh hasanah, sering mengadakan musyawarah, seringnya melibatkan masyarakat dan para remaja, memberikan dampak positif terhadap warga Desa Jegulo RT. 14 dalam mengubah mindsetnya menjadi lebih baik. Saat ini warga Desa Jegulo berlomba-lomba dalam kebaikan seperti semangat bergotong royong, bersikap lebih terbuka dan memiliki wawasan yang luas juga modern.

\section{DAFTAR PUSTAKA}

Burhanudin, Ilham. Tesis: Perubahan Mindset Guru PAI dalam Mengembangkan Perilaku Keberagamaan Peserta Didik. UIN Sunan Gunung Djati Bandung. 2018.

Effendy, S. Meningkatkan Performance BUMD dengan Semangat Corporatization dan Aliansi Strategis serta Transformasi Mindset. JRAB: Jurnal Riset Akutansi dan Bisnis. Vol. 15. No. 1. Maret. 2017

Hartanti, Yuli. Skripsi: Pengaruh Mindset terhadap Hasil Belajar Kimia Siswa Kelas XI IPA Madrasah Aliyah Negeri 1 Semarang. Fakultas Tarbiyah IAIN Walisongo Semarang. 2009.

Wahyuni, Sri. Tesis: Teori Keberhasilan - Kegagalan Pendampingan Anak Jalanan. Universitas Negeri Malang. 2009.

\section{Sumber Wawancara}

Juarno, Wawancara Tokoh Agama, di Desa Jegulo Kecamatan Soko Kabupaten Tuban pada tanggal 12 Agustus 2020.

Maulan, Wawancara Tokoh Masyarakat, di Desa Jegulo Kecamatan Soko Kabupaten Tuban pada tanggal 09 Agustus 2020.

Muhammad Lantip, Wawancara Ketua RT. 14, di Desa Jegulo Kecamatan Soko Kabupaten Tuban pada tanggal 16 Agustus 2020.

Syakur, Wawancara Tokoh Masyarakat, di Desa Jegulo Kecamatan Soko Kabupaten Tuban pada tanggal 15 Agustus 2020. 